\title{
Kajian Analisa Basis Data Sistem Informasi Eresearch pada STMIK STIKOM Bali
}

\author{
Study of Database Analysis of Eresearch Information System at STMIK STIKOM \\ Bali
}

\author{
Ni Ketut Dewi Ari Jayanti \\ STMIK STIKOM Bali \\ Jl. Raya Puputan No. 86 Renon Denpasar, telp. 0361244445 \\ e-mail: ari.jayanti@gmail.com
}

\begin{abstract}
Abstrak
STMIK STIKOM Bali yang lebih dikenal dengan STIKOM Bali merupakan salah satu Perguruan Tinggi swasta di Bali yang berbasiskan pada teknologi informasi. Jumlah dosen tetap yang bernaung dibawah tiga Program Studi sebanyak 165 Dosen. Untuk meningkatkan Mutu Pendidikan pada lingkup STIKOM Bali, perlu dilakukan berbagai upaya pembinaan dan optmalisasi terhadap Dosen dalam melaksanakan Tri Darma Perguruan Tinggi yaitu pengajaran, penelitian dan pengabdian kepada masyarakat. Khusus untuk pelaksanaan penelitian dan pengabdian kepada masyarakat, STIKOM Bali memiliki sebuah unit kerja yaitu bagian P2M (Penelitian dan Pengabdian kepada Masyarakat) dalam pengelolaan proses pelaksanaan penelitian dan pengabdian kepada masyarakat. Dalam menyikapi perkembangan teknologi dan untuk mempermudah proses pengelolaan, bagian P2M mengembangkan sebuah sistem informasi yang dikenal dengan eresearch. Pada sistem eresearch tersimpan seluruh data penelitian dan pengabdian yang dilakukan oleh Dosen. Perkembangan teknologi basis data saat ini berlangsung sangat cepat. Jumlah data penelitian dan pengabdian yang diolah semakin hari juga semakin meningkat. Permasalahan yang muncul adalah bagaimana melakukan analisa basis data yang dapat mempermudah pengolahan dan pengaturan basis data tersebut. Jumlah data yang masuk harus terintegrasi, tepat dan aktual. Data yang masuk tersebut harus diolah dan diatur sedemikian rupa sehingga memenuhi ketentuan untuk masuk ke basis data. Hal tersebut melatarbelakangi penelitian kajian analisa basis data. Metode yang digunakan dalam kajian ini adalah feasibility study. Hasil yang sudah diperoleh pada penelitian ini terdiri atas analisa terhadap proses yang sedang berjalan pada sistem eresearch, permasalahan yang ada serta usulan pemecahan masalah, perancangan basis data yang terdiri atas perancangan konseptual, logical, dan fisikal. Hasil penelitian ini dapat digunakan oleh pengembang sistem dalam mengolah serta mengatur basis data pada sistem informasi eresearch STMIK STIKOM Bali.
\end{abstract}

Kata kunci: Sistem Informasi, Basis Data, Studi Kelayakan

\section{Abstract}

STMIK STIKOM Bali, better known by STIKOM Bali is one of the private universities in Bali based on information technology. Number of permanent lecturer who shelter under three 165 Lecturer Program. To improve the Quality of Education in Bali STIKOM scope, need to do a variety of development efforts and optmalisasi against Lecturer in implementing the Tri Darma Higher Education, namely teaching, research and community service. Especially for the conduct of research and dedication to the community, STIKOM Bali has a working unit that is part of P2M (Research and Community Service) in the management of the implementation process of research and community service. In addressing the development of technology and to simplify the process of managing, part P2M develop an information system known as eresearch. In all data stored eresearch system research and service conducted by Lecturer. The development of database technology is currently underway very quickly. The amount of data research and service processed more days also increased. The problem that arises is how to analyze a database which can simplify the processing and setting the database. The amount of 
incoming data must be integrated, accurate and current. The incoming data must be processed and arranged in a way that meets the conditions for entry into the database. This background of the research study analyzes the data base. The method used in this study is a feasibility study. The results that have been obtained in this study consisted of an analysis of the processes that are running on the system eresearch, the existing problems and proposed solutions, database design consists of designing the conceptual, logical, and physical. The results of this study can be used by system developers to process and organize data on the basis of information systems eresearch STMIK STIKOM Bali.

Keywords: Information System, Database, Feasibility Study

\section{PENDAHULUAN}

STMIK STIKOM Bali yang lebih dikenal dengan STIKOM Bali merupakan salah satu Perguruan Tinggi swasta di Bali yang berbasiskan pada teknologi informasi. Saat ini STIKOM Bali memiliki dua Program Studi jenjang Strata 1 yaitu Sistem Komputer dan Sistem Informasi serta 1 Program Studi jenjang Diploma 3 yaitu Manajemen Informatika. Jumlah dosen tetap yang bernaung dibawah tiga Program Studi tersebut sebanyak 165 Dosen (forlap.dikti.go.id)[1]. Untuk meningkatkan Mutu Pendidikan pada lingkup STIKOM Bali, perlu dilakukan berbagai upaya pembinaan dan optmalisasi terhadap Dosen dalam melaksanakan Tri Darma Perguruan Tinggi yaitu pengajaran, penelitian dan pengabdian kepada masyarakat.

Khusus untuk pelaksanaan penelitian dan pengabdian kepada masyarakat, STIKOM Bali memiliki sebuah unit kerja yaitu bagian P2M (Penelitian dan Pengabdian kepada Masyarakat) dalam pengelolaan proses pelaksanaan penelitian dan pengabdian kepada masyarakat. Dalam menyikapi perkembangan teknologi dan untuk mempermudah proses penglolaan, bagian P2M mengembangkan sebuah sistem informasi yang dikenal dengan eresearch. Pada sistem eresearch tersimpan seluruh data penelitian dan pengabdian yang dilakukan oleh Dosen.

Pada penelitian sebelumnya yang dilakukan oleh Didik Hardijanto pada penelitiannya yang berjudul Kajian Basis Data Dalam Sistem Informasi Terpadu Pembangunan Prasarana Dan Sarana Dasar Perkotaan Di Kota Besar (Studi Kasus : Kota Bekasi), mengemukakan bahwa dalam pengelolaan basis data masih terlihat adanya tingkat kepuasan yang masih rendah dalam perolehan data (30 instansi) sehingga mendorong instansi untuk melakukan survey sendiri dikarenakan data yang didapatkan dart instansi lain kurang akurat/kurang aktual yaitu 53,84 \%. Dalam mengembangkan model basis data perlu diperhatikan kemudahan, biaya, keluwesan, kepraktisan serta dukungan interface yang ditujukan untuk end-user sehingga implementasi dari aplikasi basis data dapat dioperasikan dengan mudah oleh end-user. Disamping pertimbangan tersebut perlu juga dipertimbangkan kompatibilitas dan lokasi dari masing-masing instansi tidak berada pada satu lokasi tetapi pada beberapa node untuk itu disarankan dengan memperhatikan model jaringan yang lebih cepat dan efisien dengan beban Server pusat dapat dikurangi sehingga operasi lebih cepat, mudah dan murah dalam pemeliharaan[2].

Penelitian lainnya, dilakukan oleh Edhy Sutanta pada penelitiannya yang berjudul Distribusi Basis Data Kependudukan Untuk Optimalisasi Akses Data: Suatu Kajian Pustaka, mengemukakan bahwa skenario distribusi database untuk database kependudukan merupakan hal penting dan layak diterapkan mengingat sentralisasi database memiliki banyak kelemahan. Tulisan ini mengungkap sebuah gagasan tentang skenario penerapan distribusi database kependudukan WNI yang meliputi skenario database master kependudukan nasional tunggal 
dan terpusat, desain logik pengembangan database kependudukan, desain fisik pengembangan database kependudukan, distribusi database kependudukan, replikasi dan fragmentasi database, serta aspek transparansi dalam DDBMS [3].

Perkembangan teknologi basis data saat ini berlangsung sangat cepat. Jumlah data penelitian dan pengabdian yang diolah semakin hari juga semakin meningkat. Permasalahan yang muncul adalah bagaimana melakukan analisa basis data yang dapat mempermudah pengolahan dan pengaturan basis data tersebut. Jumlah data yang masuk harus terintegrasi, tepat dan aktual. Data yang masuk tersebut harus diolah dan diatur sedemikian rupa sehingga memenuhi ketentuan untuk masuk ke basis data. Hal tersebut melatarbelakangan penelitian kajian analisa basis data. Kajian analisa ini diharapkan dapat membantu pengembang sistem dalam mengolah dan mengatur basis data pada sistem informasi eresearch.

Adapun luaran yang dihasilkan pada penelitian ini adalah dokumen perancangan basis data sistem informasi eresearch STIKOM Bali yang terdiri atas : (1)Perancangan konseptual, yaitu (i) Identifikasi tipe entitas, (ii) Identifikasi tipe relasi, (iii) Identifikasi dan asosiasi atribut dengan entitas atau tipe relasi dan (iv) Memeriksa redudansi ; (2)Perancangan logical, yaitu : (i) Derive relation untuk model data logikal dan (ii) Penentuan batas integritas ; (4) Perancangan fisikal, yaitu (i). Pemberian indeks pada file dan (ii) Mekanisme keamanan.

\section{METODE PENELITIAN}

Adapun tahapan-tahapan yang akan dilaksanakan adalah sebagai berikut:

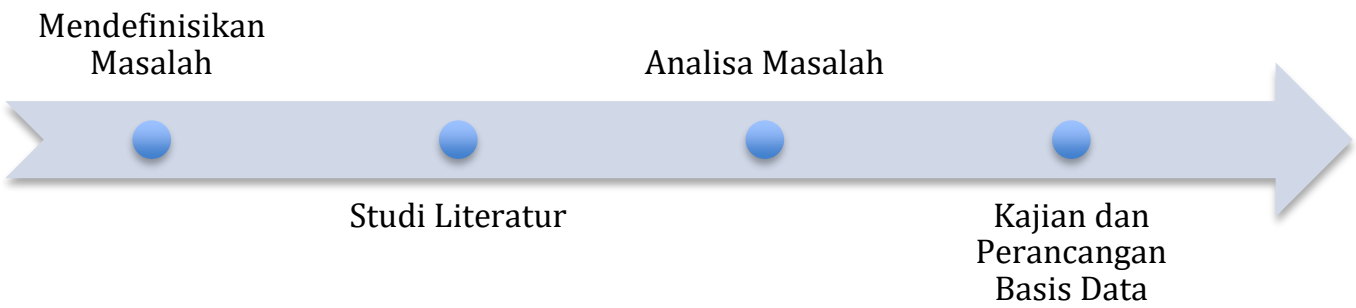

Gambar 1. Alur Penelitian

2.1 Mendefinisikan Masalah

Mendifinisikan masalah merupakan tahapan menentukan permasalahan yang ada berkaitan dengan kajian analisa basis data sistem eresearch.

2.2 Studi Literatur

Tahap ini melakukan pengumpulan materi yang berasal dari tulisan-tulisan karya ilmiah, artikel populer, serta tanggapan dari praktisi dan profesional mengenai kajian basis data.

\subsubsection{Basis Data}

Basis data adalah suatu kumpulan yang terbagi-bagi dalam data yang terhubung secara logikal dan sebuah deskripsi pada data tersebut, dibuat untuk memenuhi kebutuhan informasi dalam sejumlah perusahaan [4]. Basis data atau disebut juga Database adalah suatu kumpulan data tersimpan dalam sebuah format terstandarisasi, didesain untuk dibagi-bagikan oleh user berkali-kali [5].

Berdasarkan definisi yang sudah dijelaskan diatas, dapat disimpulkan bahwa basis data adalah sekumpulan data yang terintegrasi yang terbagi-bagi dalam data yang terhubung secara 
logical dan juga tersimpan dalam sebuah format terstandarisasi dan dibuat untuk memenuhi kebutuhan informasi dalam sejumlah organisasi.

\subsubsection{Database Management System (DBMS)}

Database Management System (DBMS) adalah sebuah sistem piranti lunak yang memungkinkan user untuk menjelaskan, membuat, mengatur, dan control access ke basis data [4]. Secara tipikal sebuah DBMS menyediakan fasilitas dibawah ini [5] :

1. Data Definition Language (DDL)

DDL ini memungkinkan user untuk melakukan spesifikasi tipe data, struktur datanya dan constraint pada data yang akan disimpan ke basis data.

2. Data Manipulation Language (DML)

Memungkinkan user untuk menyisipkan, mengubah, menghapus dan mengembalikan data dari basis data, biasanya menuju sebuah Data Manipulation Language (DML).

3. Menyediakan akses terkontrol terhadap database. contohnya sebagai berikut:

- Sebuah security system, mencegah user yang tidak memiliki hak akses database.

- Sejumlah integrity system, mengatur konsistensi pada data yang tersimpan.

- Sebuah concurrency control system, mengijinkan shared access pada database.

- Sebuah recovery control system, mengembalikan database menuju sebuah status konsisten sebelumnya berikut kegagalan sebuah hardware dan software.

\subsubsection{Siklus Basis Data}

Berdasarkan kajian teori basis data, siklus basis data terdiri atas 9 siklus yang digambarkan pada Gambar 2[6].

1. Database Planning

Pada aktifitas ini akan disusun bagaimana langkah siklus hidup dapat direalisasikan secara lebih efisien dan efektif.

2. System Definition

Definisi ruang lingkup basis data (Misal : user,aplikasi,dan sebagainya).

3. Database Design

Pada bagian dari fase ini, perancangan sistem basis data secara konseptual, logikal, dan fisikal dikerjakan.

Pada bagian perancangan database ini terdapat 3 tahap utama yaitu :

1. Conceptual database design

Tahapan-tahapan untuk merancangan sebuah conceptual database yakni:

Tahap 1 : Membangun Model Data konseptual local untuk setiap view

Tahap $1.1 \quad$ : Mengidentifikasikan entitas.

Tahap 1.2 : Mengidentifikasikan hubungan.

Tahap 1.3 : Mengidentifikasikan dan menghubungkan atribut dengan entitas atau relasinya.

Tahap $1.4 \quad$ : Menentukan domain atribut.

Tahap 1.5 : Menentukan Atribut-atribut Candidate, Primary, dan Alternate Key.

Tahap 1.6 : Mempertimbangkan Penggunaan dari konsep permodelan Enhanced.

Tahap 1.7 : Memeriksa Model untuk Redudansi.

Tahap 1.8 : Melakukan Validasi Model Konseptual local terhadap transaksi user.

Tahap $1.9 \quad$ : Meninjau ulang model data konseptual dengan 
user.

2. Logical Database Design

Tahap-tahap dalam merancang basis data logikal yaitu:

Tahap 2 : Membangun dan melakukan validasi model data logikal global untuk setiap sudut pandang.

Tahap $2.1 \quad$ : Menghilangkan bagian yang tidak sesuai dengan model relasi.

Tahap 2.2 : Validasi relasi dengan menggunakan teknik normalisasi.

Tahap 2.3 : Validasi relasi dengan transaksi-transaksi yang sesuai dengan kebutuhan user.

Tahap 2.4 : Menentukan batasan-batasan integritas.

Tahap 2.5 : Meninjau ulang model data logikal lokal terhadap kebutuhan user.

Tahap 2.6 : Menggabungkan model dan logikal lokal ke dalam model data logikal global.

Tahap 2.6.1 : Menggabungkan model data logikal lokal kedalam model data logikal global.

Tahap 2.6.2 : Melakukan validasi model data logikal global.

Tahap 2.6.3: Meninjau ulang model data logikal global terhadap kebutuhan user.

Tahap 2.7 : Memeriksa model data untuk kebutuhan masa depan.

3. Physical Database Design

Tahapan-tahapan dalam merancang basis data fisikal :

Tahap 3 : Menerjemahkan model data logikal global untuk DBMS yang digunakan.

Tahap 3.1 : Merancang Relasi Dasar.

Tahap 3.2 : Merancang Representasi dari Derived Data.

Tahap 3.3 : Merancang Batasan Umum.

Tahap 4 : Merancang Representasi Fisikal

Tahap 4.1: Menganalisa Transaksi.

Tahap 4.2 : Memilih Organisasi File.

Tahap 4.3 : Memilih Indeks.

Tahap 4.4 : Memperkirakan kebutuhan disk space.

Tahap 5 : Perancangan User Views.

Tahap 6 : Perancangan Mekanisme Keamanan.

Tahap 7 : Mempertimbangkan Kemunculan Redundansi Terkontrol.

Tahap 7.1 : Menggabungkan relasi 1:1.

Tahap 7.2 : Melakukan duplikasi pada atribut non key pada relasi $1:^{*}$ untuk mengurangi penggunaan join.

Tahap 7.3 : Melakukan duplikasi pada atribut foreign key pada relasi 1:* untuk mengurangi join.

Tahap 7.4 : Melakukan duplikasi pada atribut pada relasi *:* untuk mengurangi penggunaan join.

Tahap 7.5 : Mengenali Repeating groups.

Tahap 7.6 : Menggabungkan lookup table dengan relasi dasar. 
Tahap 7.7 : Membuat tabel ekstraksi.

Tahap 8 : Memonitor Sistem Operasional.

4. Implementation

Pemrosesan dan penulisan definisi basis data secara konseptual, logikal dan fisikal dikerjakan.

5. Loading atau Data Conversion

Basis data ditempatkan baik secara memanggil data secara langsung ataupun merubah file-file yang ada ke dalam format sistem basis data dan memanggilnya kembali.

6. Application Conversion

Beberapa aplikasi software dari suatu sistem sebelumnya diganti dengan sistem yang baru.

7. Testing and Validation

Sistem yang baru dites dan diuji kebenarannya.

8. Operation

Operasi-operasi pada sistem basis data dan aplikasi-aplikasinya.

9. Monitoring and Maintenance

Merupakan proses untuk mengawasi dan memelihara suatu sistem basis data selama sistem tersebut dikerjakan.

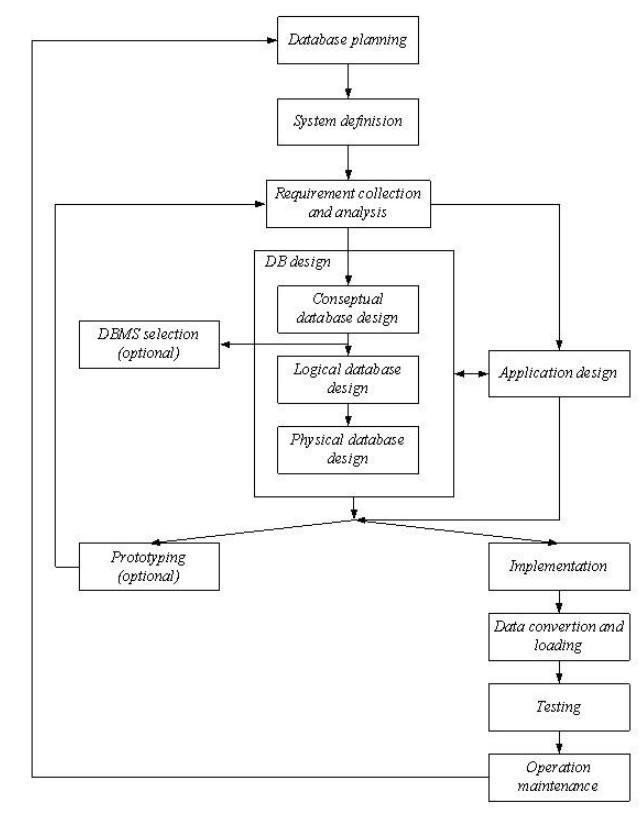

Gambar 2. Database Lifecycle[6]

\subsubsection{Feasibility Study}

Feasibility study adalah suatu studi atau pengkajian apakah suatu usulan proyek/gagasan usaha apabila dilaksanakan dapat berjalan dan berkembang sesuai dengan tujuannya atau tidak [7]. Sementara pendapat lain mengemukakan bahwa feasibility study adalah kegiatan untuk menilai sejauh mana manfaat yang dapat diperoleh dalam melaksanakan suatu kegiatan usaha /proyek dan merupakan bahan pertimbangan dalam mengambil suatu keputusan, apakah menerima atau menolak dari suatu gagasan usaha /proyek yang direncanakan. Pengertian layak dalam penilaian ini adalah kemungkinan dari gagasan usaha/proyek yang akan dilaksanakan memberikan manfaat (benefit), baik dalam arti financial benefit maupun dalam arti social 
benefit. Layaknya suatu gagasan usaha/proyek dalam arti social benefit tidak selalu menggambarkan dalam arti financial benefit, hal ini tergantung dari segi penilaian yang dilakukan [8].

Berdasarkan kedua pendapat tersebut dapatlah disimpulkan bahwa studi kelayakan adalah kegiatan menganalisa, mengkaji dan menelilti berbagai aspek tertentu suatu gagasan usaha/proyek yang akan dilaksanakan atau telah dilaksanakan, sehingga memberi gambaran layak atau tidak layak suatu gagasan usaha/proyek apabila ditinjau dari manfaat yang dihasilkan dari proyek/gagasan usaha tersebut baik dari susut financial benefit maupun social benefit.

\subsection{Analisa Masalah}

Melakukan proses analisa terhadap permasalahan yang dibahas serta memberikan usulan pemecahan masalah.

\subsection{Kajian dan Perancangan Basis Data}

Kajian dan perancangan basis data dilakukan berdasarkan hasil yang diperoleh dari tahap analisa masalah. Metode yang digunakan dalam penelitian kajian basis data ini adalah feasibility study. Pada feasibility study, identifikasi terhadap kebutuhan basis data dilakukan. Identifikasi tidak hanya didasarkan oleh kebutuhan baru, namun juga memperhatikan kebutuhan pada sistem eresearch yang sudah ada. Hasil feasibility study berupa daftar kebutuhan basis data dan juga solusi yang dikehendaki.

Perancangan basis data yang dihasilkan terdiri atas perancangan konseptual, perancangan logical dan perancangan fisikal. Berikut perancangan basis data yang akan dihasilkan terdiri atas

a. Perancangan konseptual, yaitu :

i. Identifikasi tipe entitas

ii. Identifikasi tipe relasi

iii. Identifikasi dan asosiasi atribut dengan entitas atau tipe relasi

iv. Memeriksa redudansi

b. Perancangan logical, yaitu :

i. Derive relation untuk model data logical

ii. Penentuan batas integritas

c. Perancangan fisikal, yaitu :

i. Pemberian indeks pada file

ii. Mekanisme keamanan

\section{HASIL DAN PEMBAHASAN}

3.1 Proses Yang Sedang Berjalan

Sistem informasi eresearch dikembangkan oleh tim pengembang unit Penelitian dan Pengabdian kepada Masyarakat (P2M) STIKOM Bali. Saat ini pengguna sistem informasi eresearch terdiri dari :

1. Super Admin, pengguna yang dapat mengakses segala fungsi didalam sistem

2. Admin Penelitian, pengguna yang dapat mengelola data penelitian internal

3. Admin Pengabdian, pengguna yang dapat mengelola data pengabdian internal

4. Reviewer Penelitian, pengguna yang dapat menjalankan fungsi review penelitian internal 
5. Reviewer Pengabdian, pengguna yang dapat menjalankan fungsi review pengabdian internal

6. Redaksi, pengguna yang dapat menjalankan fungsi redaksi dari penelitian dan pengabdian

7. Dosen Pengusul, pengguna yang dalam hal ini adalah dosen pengusul yang dapat menjalankan fungsi pengusulan penelitian internal dan pengabdian internal.

Secara garis besar dapat dijabarkan proses yang sedang berjalan pada sistem informasi eresearch adalah sebagai berikut :

1. Diawal, super admin membuka usulan, baik itu usulan penelitian maupun pengabdian.

2. Dosen pengusul melakukan input usulan baik itu penelitian maupun pengabdian dan mengunggah proposal pada sistem eresearch.

3. Admin penelitian dan atau admin pengabdian melakukan ploting reviewer penelitian dan atau pengabdian serta ploting redaksi.

4. Reviewer penelitian dan atau pengabdian melakukan review proposal dosen pengusul, dan memberikan penilaian serta komentar.

5. Redaksi mengecek penulisan serta persyaratan administrasi pengusul.

6. Admin penelitian dan pengabdian merekap hasil review dari reviewer dan redaksi.

Secara detail proses yang sedang berjalan digambarkan melalui Data Flow Diagram (DFD).

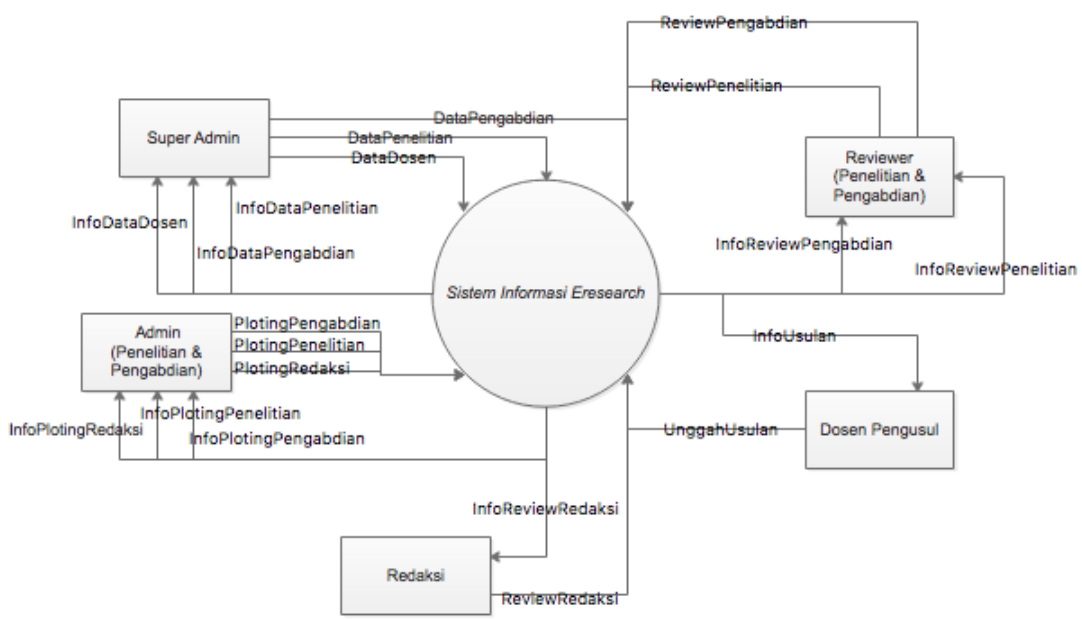

Gambar 3. DFD Sistem Informasi Eresearch

\subsection{Permasalahan Yang Ada}

Saat ini total jumlah Dosen tetap STIKOM Bali yang dapat mengusulkan penelitian dan pengabdian sebanyak 178 Dosen. Jumlah dosen akan meningkat setiap tahun sehingga jumlah data penelitian dan pengabdian yang diolah semakin hari juga semakin meningkat. Permasalahan yang muncul adalah bagaimana melakukan analisa basis data yang dapat mempermudah pengolahan dan pengaturan basis data tersebut. Jumlah data yang masuk harus terintegrasi, tepat dan aktual. Data yang masuk tersebut harus diolah dan diatur sedemikian rupa sehingga memenuhi ketentuan untuk masuk ke basis data.

\subsection{Usulan Pemecahan Masalah}

Menyikapi permasalahan yang ada, diusulkan suatu pemecahan masalah yaitu dengan melakukan studi kelayakan mengkaji suatu analisa basis data. Kajian analisa ini diharapkan 
dapat membantu pengembang sistem dalam mengolah dan mengatur basis data pada sistem informasi eresearch. Dilakukan perancangan basis data yang terdiri atas perancangan konseptual, perancangan logikal, dan perancangan fisikal.

\subsection{Perancangan Basis Data}

Perancangan basis data meliputi tiga tahap, yaitu perancangan basis data konseptual, perancangan basis data logikal dan perancangan basis data fisikal.

\subsubsection{Perancangan Konseptual}

Perancangan basis data konseptual adalah proses membangun sebuah rancangan informasi yang dipusatkan pada pemrosesan suatu model dari informasi yang akan digunakan dalam suatu organisasi dan bebas dari pertimbangan fisikal. Tujuan dari perancangan ini untuk membuat representasi konseptual dari basis data yang meliputi identifikasi dari entitas, relasi dan atribut.

Perancangan basis data konseptual terdiri dari empat tahap perancangan, yaitu:

1. Identifikasi tipe entitas.

2. Identifikasi tipe relasi.

3. Identifikasi dan asosiasi atribut dengan entitas atau tipe relasi.

4. Memeriksa redundansi.

Berikut pembahasan masing-masing tahapan :

A. Identifikasi tipe entitas

Tabel berikut merupakan tabel yang menjelaskan entitas yang menjadi kebutuhan pada sistem informasi eresearch.

Tabel 1 Identifikasi Tipe Entitas

\begin{tabular}{|c|c|c|c|c|}
\hline No. & Nama Entitas & Deskripsi & Alias & Kejadian \\
\hline 1 & TbSuperAdmin & $\begin{array}{l}\text { Berisi semua } \\
\text { data mengenai } \\
\text { super admin }\end{array}$ & $\begin{array}{l}\text { SuperAdmi } \\
\mathrm{n}\end{array}$ & $\begin{array}{l}\text { Bertugas sebagai } \\
\text { super admin yang } \\
\text { mengelola seluruh } \\
\text { data pada sistem } \\
\text { informasi } \\
\text { eresearch }\end{array}$ \\
\hline 2 & TbAdmin & $\begin{array}{l}\text { Berisi semua } \\
\text { data mengenai } \\
\text { admin }\end{array}$ & Admin & $\begin{array}{l}\text { Bertugas sebagai } \\
\text { admin yang } \\
\text { mengelola data } \\
\text { penelitian dan } \\
\text { pengabdian internal }\end{array}$ \\
\hline 3 & TbRedaksi & $\begin{array}{l}\text { Berisi semua } \\
\text { data mengenai } \\
\text { redaksi }\end{array}$ & Redaksi & $\begin{array}{l}\text { Bertugas sebagai } \\
\text { redaksi yang dapat } \\
\text { menjalankan fungsi } \\
\text { redaksi dari } \\
\text { penelitian dan } \\
\text { pengabdian internal }\end{array}$ \\
\hline 4 & TbReviewer & $\begin{array}{l}\text { Berisi semua } \\
\text { data mengenai } \\
\text { reviewer }\end{array}$ & Reviewer & $\begin{array}{l}\text { Bertugas sebagai } \\
\text { reviewer yang } \\
\text { dapat menjalankan } \\
\text { fungsi review } \\
\text { penelitian dan } \\
\text { pengabdian internal }\end{array}$ \\
\hline
\end{tabular}




\begin{tabular}{|c|c|c|c|c|}
\hline No. & Nama Entitas & Deskripsi & Alias & Kejadian \\
\hline 5 & $\int_{1}$ TbDosenPengusu & $\begin{array}{l}\text { Berisi semua } \\
\text { data mengenai } \\
\text { dosen pengusul }\end{array}$ & Pengusul & $\begin{array}{l}\text { Bertugas sebagai } \\
\text { dosen pengusul } \\
\text { yang dapat } \\
\text { menjalankan fungsi } \\
\text { pengusulan } \\
\text { penelitian dan } \\
\text { pengabdian } \\
\text { internal. }\end{array}$ \\
\hline 6 & . TbUsulan & $\begin{array}{l}\text { Berisi semua } \\
\text { data mengenai } \\
\text { usulan } \\
\text { penelitian dan } \\
\text { pengabdian }\end{array}$ & Usulan & $\begin{array}{l}\text { Usulan/ proposal } \\
\text { penelitian dan } \\
\text { pengabdian internal }\end{array}$ \\
\hline 7 & \$. TbKemajuan & $\begin{array}{l}\text { Berisi semua } \\
\text { data mengenai } \\
\text { laporan } \\
\text { kemajuan } \\
\text { penelitian dan } \\
\text { pengabdian }\end{array}$ & Kemajuan & $\begin{array}{l}\text { Laporan kemajuan } \\
\text { penelitian dan } \\
\text { pengabdian internal }\end{array}$ \\
\hline 8 & TbAkhir & $\begin{array}{l}\text { Berisi semua } \\
\text { data mengenai } \\
\text { laporan akhir } \\
\text { penelitian dan } \\
\text { pengabdian }\end{array}$ & Akhir & $\begin{array}{l}\text { Laporan akhir } \\
\text { penelitian dan } \\
\text { pengabdian internal }\end{array}$ \\
\hline
\end{tabular}

B. Identifikasi tipe relasi

Tujuan dari langkah ini ialah untuk menentukan hubungan yang terjadi antara tipe-tipe entitas yang telah diidentifikasi. Berikut ini merupakan hubungan-hubungan antar entitas yang telah diidentifikasi:

Tabel 2 Identifikasi Tipe Relationship antar Entitas

\begin{tabular}{|c|c|l|l|c|}
\hline Nama Entitas & Kardinalitas & Nama Relasi & Nama Entitas & Kardinalitas \\
\hline \multirow{3}{*}{ TbRedaksi } & 1 & Meredaksi & TbUsulan & $\mathrm{N}$ \\
& 1 & Meredaksi & TbKemajuan & $\mathrm{N}$ \\
& 1 & Meredaksi & TbAkhir & $\mathrm{N}$ \\
\hline TbDosenPengusul & 1 & Memiliki & TbUsulan & $\mathrm{N}$ \\
\hline \multirow{2}{*}{ TbUsulan } & 1 & Memiliki & TbKemajuan & 1 \\
& 1 & Memiliki & TbAkhir & 1 \\
\hline \multirow{3}{*}{ TbReviewer } & $\mathrm{N}$ & Mereview & TbUsulan & $\mathrm{N}$ \\
& $\mathrm{N}$ & Mereview & TbKemajuan & $\mathrm{N}$ \\
& $\mathrm{N}$ & Mereview & TbAkhir & $\mathrm{N}$ \\
\hline
\end{tabular}

C. Identifikasi dan asosiasi atribut dengan entitas atau tipe relasi. 
Setelah mengidentifikasi tipe-tipe entitas serta relationship antar entitas, langkah selanjutnya adalah mengasosiasikan atribut-atribut dengan tipe entitas dan relationship yang sesuai.

Tabel 3 Identifikasi Entitas TbSuperAdmin

\begin{tabular}{|c|c|c|c|c|c|}
\hline Nama Entitas & Atribut & Deskripsi & $\begin{array}{c}\text { Tipe } \\
\text { Data \& } \\
\text { Panjang } \\
\text { Data }\end{array}$ & Nulls & Multivalued \\
\hline \multirow[t]{6}{*}{ TbSuperAdmin } & KodeSuperAdmin & $\begin{array}{l}\text { Kode } \\
\text { super } \\
\text { admin }\end{array}$ & $\begin{array}{l}\text { Varchar } \\
\text { (5) }\end{array}$ & No. & No. \\
\hline & Username & $\begin{array}{l}\text { Username } \\
\text { super } \\
\text { admin }\end{array}$ & $\begin{array}{l}\text { Varchar } \\
\text { (15) }\end{array}$ & No. & No. \\
\hline & Password & $\begin{array}{l}\text { Password } \\
\text { super } \\
\text { admin }\end{array}$ & $\begin{array}{l}\text { Varchar } \\
\text { (20) }\end{array}$ & No. & No. \\
\hline & NamaSuperAdmin & $\begin{array}{l}\text { Nama } \\
\text { super } \\
\text { admin }\end{array}$ & $\begin{array}{l}\text { Varchar } \\
\text { (100) }\end{array}$ & No. & No. \\
\hline & PhoneSuperAdmin & $\begin{array}{l}\text { No. } \\
\text { telepon } \\
\text { super } \\
\text { admin }\end{array}$ & $\begin{array}{l}\text { Varchar } \\
\text { (20) }\end{array}$ & No. & Yes. \\
\hline & AlamatSuperAdmin & $\begin{array}{l}\text { Alamat } \\
\text { super } \\
\text { admin }\end{array}$ & $\begin{array}{l}\text { Varchar } \\
\text { (100) }\end{array}$ & No. & No. \\
\hline
\end{tabular}

Tabel 4 Identifikasi Entitas TbAdmin

\begin{tabular}{|l|l|l|l|c|c|}
\hline \multirow{2}{*}{ Nama Entitas } & Atribut & Deskripsi & $\begin{array}{c}\text { Tipe } \\
\text { Data \& } \\
\text { Panjang } \\
\text { Data }\end{array}$ & Nulls & Multivalued \\
\hline TbAdmin & KodeAdmin & $\begin{array}{l}\text { Kode } \\
\text { admin }\end{array}$ & $\begin{array}{l}\text { Varchar } \\
(5)\end{array}$ & No. & No. \\
\cline { 2 - 6 } & Username & $\begin{array}{l}\text { Username } \\
\text { admin }\end{array}$ & $\begin{array}{l}\text { Varchar } \\
(15)\end{array}$ & No. & No. \\
\cline { 2 - 6 } & Password & $\begin{array}{l}\text { Password } \\
\text { admin }\end{array}$ & $\begin{array}{l}\text { Varchar } \\
(20)\end{array}$ & No. & No. \\
\cline { 2 - 6 } & NamaAdmin & $\begin{array}{l}\text { Nama } \\
\text { admin }\end{array}$ & $\begin{array}{l}\text { Varchar } \\
(100)\end{array}$ & No. & No. \\
\cline { 2 - 6 } & PhoneAdmin & $\begin{array}{l}\text { No. } \\
\text { telepon } \\
\text { admin }\end{array}$ & $\begin{array}{l}\text { Varchar } \\
(20)\end{array}$ & No. & Yes. \\
\hline
\end{tabular}




\begin{tabular}{|l|l|l|l|l|l|}
\hline Nama Entitas & Atribut & Deskripsi & $\begin{array}{c}\text { Tipe } \\
\text { Data \& } \\
\text { Panjang } \\
\text { Data }\end{array}$ & Nulls & Multivalued \\
\hline & AlamatAdmin & $\begin{array}{l}\text { Alamat } \\
\text { admin }\end{array}$ & $\begin{array}{l}\text { Varchar } \\
(100)\end{array}$ & No. & No. \\
\hline
\end{tabular}

Tabel 5 Identifikasi Entitas TbRedaksi

\begin{tabular}{|l|l|l|l|l|c|}
\hline \multirow{5}{*}{ Nama Entitas } & \multicolumn{1}{|c|}{ Atribut } & Deskripsi & $\begin{array}{c}\text { Tipe } \\
\text { Data \& } \\
\text { Panjang } \\
\text { Data }\end{array}$ & Nulls & Multivalued \\
\hline TbRedaksi & KodeRedaksi & $\begin{array}{l}\text { Kode } \\
\text { redaksi }\end{array}$ & $\begin{array}{l}\text { Varchar } \\
(5)\end{array}$ & No. & No. \\
\cline { 2 - 7 } & Username & $\begin{array}{l}\text { Username } \\
\text { redaksi }\end{array}$ & $\begin{array}{l}\text { Varchar } \\
(15)\end{array}$ & No. & No. \\
\cline { 2 - 7 } & Password & $\begin{array}{l}\text { Password } \\
\text { redaksi }\end{array}$ & $\begin{array}{l}\text { Varchar } \\
(20)\end{array}$ & No. & No. \\
\cline { 2 - 7 } & NamaRedaksi & $\begin{array}{l}\text { Nama } \\
\text { redaksi }\end{array}$ & $\begin{array}{l}\text { Varchar } \\
(100)\end{array}$ & No. & No. \\
\cline { 2 - 7 } & PhoneRedaksi & $\begin{array}{l}\text { No. } \\
\text { telepon } \\
\text { redaksi }\end{array}$ & $\begin{array}{l}\text { Varchar } \\
(20)\end{array}$ & No. & Yes. \\
\cline { 2 - 7 } & AlamatRedaksi & $\begin{array}{l}\text { Alamat } \\
\text { redaksi }\end{array}$ & $\begin{array}{l}\text { Varchar } \\
(100)\end{array}$ & No. & No. \\
\cline { 2 - 7 } & & &
\end{tabular}

Tabel 6 Identifikasi Entias TbReviewer

\begin{tabular}{|l|l|l|l|c|c|}
\hline Nama Entitas & \multicolumn{1}{|c|}{ Atribut } & Deskripsi & $\begin{array}{c}\text { Tipe } \\
\text { Data \& } \\
\text { Panjang } \\
\text { Data }\end{array}$ & Nulls & Multivalued \\
\hline TbReviewer & KodeReviewer & $\begin{array}{l}\text { Kode } \\
\text { reviewer }\end{array}$ & $\begin{array}{l}\text { Varchar } \\
(5)\end{array}$ & No. & No. \\
\cline { 2 - 6 } & Username & $\begin{array}{l}\text { Username } \\
\text { reviewer }\end{array}$ & $\begin{array}{l}\text { Varchar } \\
(15)\end{array}$ & No. & No. \\
\cline { 2 - 6 } & Password & $\begin{array}{l}\text { Password } \\
\text { reviewer }\end{array}$ & $\begin{array}{l}\text { Varchar } \\
(20)\end{array}$ & No. & No. \\
\cline { 2 - 6 } & NamaReviewer & $\begin{array}{l}\text { Nama } \\
\text { reviewer }\end{array}$ & $\begin{array}{l}\text { Varchar } \\
(100)\end{array}$ & No. & No. \\
\cline { 2 - 6 } & PhoneReviewer & $\begin{array}{l}\text { No. } \\
\text { telepon } \\
\text { reviewer }\end{array}$ & $\begin{array}{l}\text { Varchar } \\
(20)\end{array}$ & No. & Yes. \\
\cline { 2 - 6 } & AlamatReviewer & $\begin{array}{l}\text { Alamat } \\
\text { reviewer }\end{array}$ & $\begin{array}{l}\text { Varchar } \\
(100)\end{array}$ & No. & No. \\
\hline
\end{tabular}


Tabel 7 Identifikasi Entitas TbDosenPengusul

\begin{tabular}{|c|c|c|c|c|c|}
\hline Nama Entitas & Atribut & Deskripsi & $\begin{array}{c}\text { Tipe } \\
\text { Data \& } \\
\text { Panjang } \\
\text { Data }\end{array}$ & Nulls & Multivalued \\
\hline \multirow[t]{10}{*}{$\begin{array}{l}\text { TbDosenPeng } \\
\text { usul }\end{array}$} & NIDN & $\begin{array}{l}\text { NIDN Dosen } \\
\text { Pengusul }\end{array}$ & $\begin{array}{l}\text { Varchar } \\
\text { (10) }\end{array}$ & No. & No. \\
\hline & Username & $\begin{array}{l}\text { Username } \\
\text { Dosen } \\
\text { Pengusul }\end{array}$ & $\begin{array}{l}\text { Varchar } \\
\text { (15) }\end{array}$ & No. & No. \\
\hline & Password & $\begin{array}{l}\text { Password } \\
\text { Dosen } \\
\text { Pengusul }\end{array}$ & $\begin{array}{l}\text { Varchar } \\
\text { (20) }\end{array}$ & No. & No. \\
\hline & $\begin{array}{l}\text { NamaDosenPeng } \\
\text { usul }\end{array}$ & $\begin{array}{l}\text { Nama Dosen } \\
\text { Pengusul }\end{array}$ & $\begin{array}{l}\text { Varchar } \\
(100)\end{array}$ & No. & No. \\
\hline & $\begin{array}{l}\text { PhoneDosenPeng } \\
\text { usul }\end{array}$ & $\begin{array}{l}\text { No. telepon } \\
\text { Dosen } \\
\text { Pengusul }\end{array}$ & $\begin{array}{l}\text { Varchar } \\
\text { (20) }\end{array}$ & No. & Yes. \\
\hline & $\begin{array}{l}\text { AlamatDosenPen } \\
\text { gusul }\end{array}$ & $\begin{array}{l}\text { Alamat Dosen } \\
\text { Pengusul }\end{array}$ & $\begin{array}{l}\text { Varchar } \\
(100)\end{array}$ & No. & No. \\
\hline & $\begin{array}{l}\text { DisiplinIlmuDose } \\
\text { nPengusul }\end{array}$ & $\begin{array}{l}\text { Disiplin Ilmu } \\
\text { Dosen } \\
\text { Pengusul } \\
\end{array}$ & $\begin{array}{l}\text { Varchar } \\
(50)\end{array}$ & No. & No. \\
\hline & $\begin{array}{l}\text { ProgramStudiDos } \\
\text { enPengusul }\end{array}$ & $\begin{array}{l}\text { Program studi } \\
\text { Dosen } \\
\text { Pengusul }\end{array}$ & $\begin{array}{l}\text { Varchar } \\
(50)\end{array}$ & No. & No. \\
\hline & $\begin{array}{l}\text { PangkatDosenPen } \\
\text { gusul }\end{array}$ & $\begin{array}{l}\text { Pangkat Dosen } \\
\text { Pengusul }\end{array}$ & $\begin{array}{l}\text { Varchar } \\
(50)\end{array}$ & No. & No. \\
\hline & $\begin{array}{l}\text { JabatanFungsiona } \\
\text { lDosenPengusul }\end{array}$ & $\begin{array}{l}\text { Jabatan } \\
\text { Fungsional } \\
\text { Dosen } \\
\text { Pengusul }\end{array}$ & $\begin{array}{l}\text { Varchar } \\
(50)\end{array}$ & No. & No. \\
\hline
\end{tabular}

Tabel 8 Identifikasi Entitas TbUsulan

\begin{tabular}{|l|l|l|l|l|c|}
\hline \multirow{3}{*}{ Nama Entitas } & \multicolumn{1}{|c|}{ Atribut } & Deskripsi & $\begin{array}{c}\text { Tipe } \\
\text { Data \& } \\
\text { Panjang } \\
\text { Data }\end{array}$ & Nulls & $\begin{array}{c}\text { Multivalu } \\
\text { ed }\end{array}$ \\
\hline TbUsulan & KodeUsulan & Kode Usulan & $\begin{array}{l}\text { Varchar } \\
(5)\end{array}$ & No. & No. \\
\cline { 2 - 6 } & JudulUsulan & Judul Usulan & $\begin{array}{l}\text { Varchar } \\
(100)\end{array}$ & No. & No. \\
\cline { 2 - 7 } & BidangUsulan & $\begin{array}{l}\text { Bidang } \\
\text { Usulan }\end{array}$ & $\begin{array}{l}\text { Varchar } \\
(50)\end{array}$ & No. & No. \\
\cline { 2 - 7 } & BiayaUsulan & Biaya Usulan & Integer & No. & No. \\
\hline
\end{tabular}




\begin{tabular}{|c|l|l|l|l|c|}
\hline Nama Entitas & Atribut & Deskripsi & $\begin{array}{c}\text { Tipe } \\
\text { Data \& } \\
\text { Panjang } \\
\text { Data }\end{array}$ & Nulls & $\begin{array}{c}\text { Multivalu } \\
\text { ed }\end{array}$ \\
\hline \multirow{2}{*}{} & FileUsulan & File Usulan & $\begin{array}{l}\text { LongBlo } \\
\text { b }\end{array}$ & No. & No. \\
\cline { 2 - 6 } & PeriodeUsulan & $\begin{array}{l}\text { Periode } \\
\text { Usulan }\end{array}$ & $\begin{array}{l}\text { Varchar } \\
(50)\end{array}$ & No. & No. \\
\hline
\end{tabular}

Tabel 9 Identifikasi Entitas TbKemajuan

\begin{tabular}{|l|l|l|l|l|c|}
\hline \multirow{2}{*}{ Nama Entitas } & \multicolumn{1}{|c|}{ Atribut } & Deskripsi & $\begin{array}{c}\text { Tipe } \\
\text { Data \& } \\
\text { Panjang } \\
\text { Data }\end{array}$ & $\begin{array}{c}\text { Nul } \\
\text { 1s }\end{array}$ & $\begin{array}{c}\text { Multivalu } \\
\text { ed }\end{array}$ \\
\hline TbKemajuan & KodeKemajuan & $\begin{array}{l}\text { Kode Laporan } \\
\text { Kemajuan }\end{array}$ & $\begin{array}{l}\text { Varchar } \\
(5)\end{array}$ & No. & No. \\
\cline { 2 - 6 } & FileKemajuan & $\begin{array}{l}\text { File Laporan } \\
\text { Kemajuan }\end{array}$ & $\begin{array}{l}\text { LongBlo } \\
\text { b }\end{array}$ & No. & No \\
\hline
\end{tabular}

Tabel 10 Identifikasi Entitas TbAkhir

\begin{tabular}{|l|l|l|l|l|c|}
\hline Nama Entitas & \multicolumn{1}{|c|}{ Atribut } & Deskripsi & $\begin{array}{c}\text { Tipe } \\
\text { Data \& } \\
\text { Panjang } \\
\text { Data }\end{array}$ & $\begin{array}{c}\text { Nul } \\
\text { 1s }\end{array}$ & $\begin{array}{c}\text { Multivalu } \\
\text { ed }\end{array}$ \\
\hline TbAkhir & KodeAkhir & $\begin{array}{l}\text { Kode Laporan } \\
\text { Akhir }\end{array}$ & $\begin{array}{l}\text { Varchar } \\
(5)\end{array}$ & No. & No. \\
\cline { 2 - 6 } & FileAkhir & $\begin{array}{l}\text { File Laporan } \\
\text { Akhir }\end{array}$ & $\begin{array}{l}\text { LongBlo } \\
\text { b }\end{array}$ & No. & No \\
\hline
\end{tabular}

D. Memeriksa redudansi

Tujuan menggunakan langkah ini adalah untuk memerika apakah terdapat adanya suatu entitas atau hubungan (Relationship) yang redundan (Data Berulang) dalam model database conceptual, dan menghapusnya dengan memeriksa kembali entitas yang memiliki kardinalitas 1:1. Terdapat dua relasi yang memiliki kardinalitas relasi 1:1 yaitu TbUsulan berelasi 1:1 degan TbKemajuan dan TbUsulan berelasi 1:1 dengan TbAkhir. Berikut penggambaran ERD 1:1

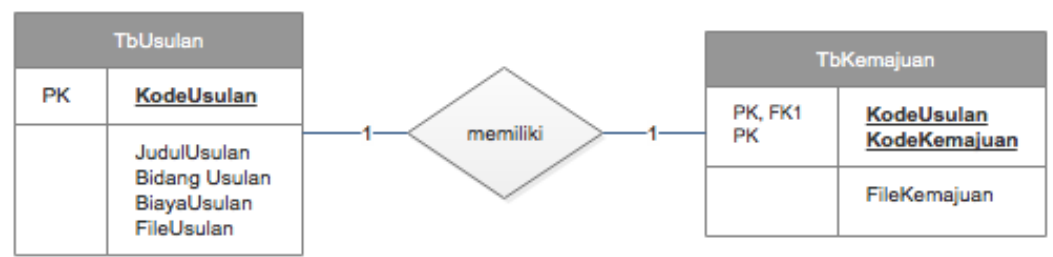

Gambar 3. ERD relasi TbUsulan dengan TbKemajuan 


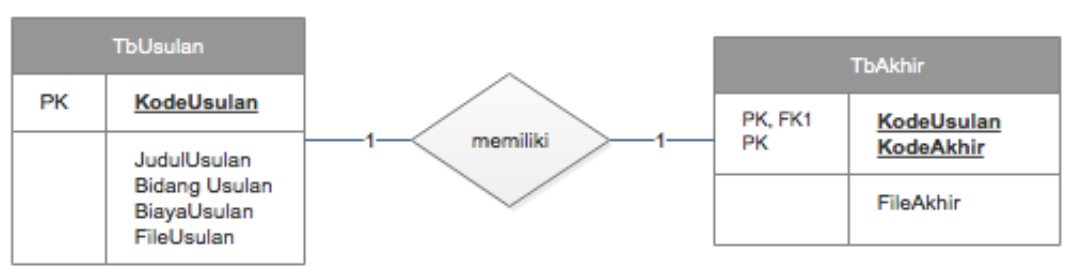

Gambar 4. ERD Relasi TbUsulan dengan TbAkhir

Berikut merupakan gambaran basis data Entity Relationship Diagaram keseluruhan Sistem Informasi Eresearch.

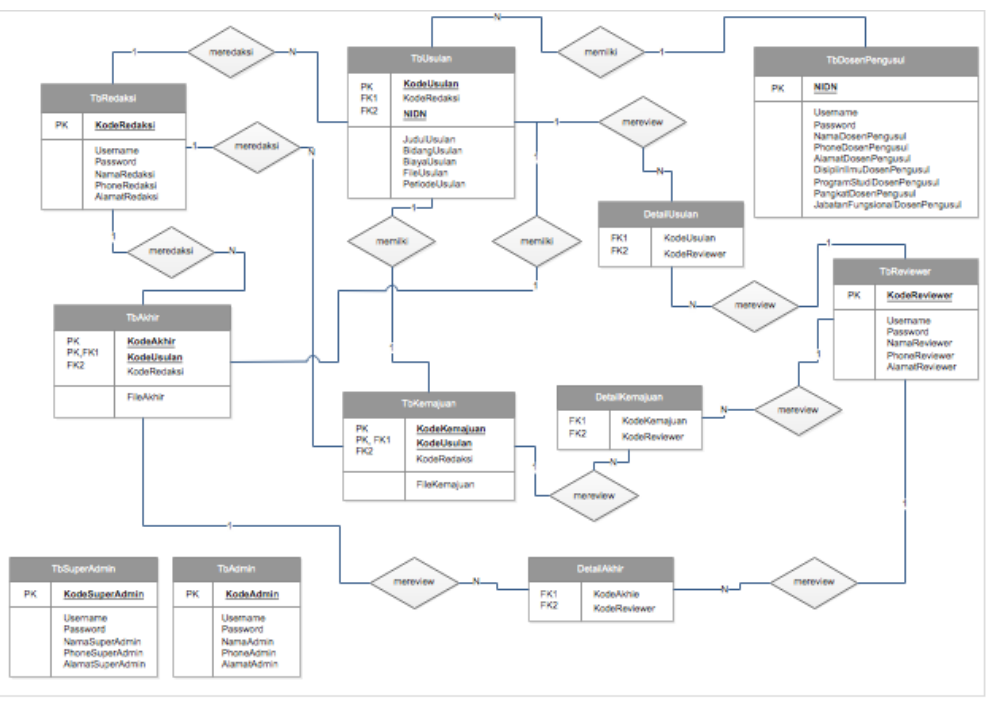

Gambar 5. Entity Relationship Diagram Sistem Informasi Eresearch

\subsubsection{Perancangan Logikal}

Perancangan basis data logikal merupakan proses membangun sebuah rancangan informasi yang digunakan dalam suatu perusahaan berbasis pada rancangan data yang spesifik, tetapi masih bebas dari penentuan DBMS dan pertimbangan fisikal yang lain. Terdapat dua tahap yang dilakukan pada perancangan basis data logikal, yaitu :

1. Derive relation untuk model data logical

2. Penentuan batas integritas

Berikut pembahasan perancangan basis data logikal.

A. Derive relation untuk model data logical

Pada tahap ini menetapkan tipe entitas kuat dan entitas lemah. Tipe entitas kuat dijelaskan dalam tabel berikut

Tabel 11 Entitas Kuat

TbSuperAdmin (KodeSuperAdmin, Username, Password, NamaSuperAdmin,

PhoneSuperAdmin, AlamatSuperAdmin)

Primary Key : KodeSuperAdmin

TbAdmin (KodeAdmin, Username, Password, NamaAdmin, PhoneAdmin,

AlamatAdmin) 
Primary Key : KodeAdmin

TbRedaksi (KodeRedaksi, Username, Password, NamaRedaksi, PhoneRedaksi, AlamatRedaksi)

Primary Key : KodeRedaksi

TbReviewer (KodeReviewer, Username, Password, NamaReviewer,

PhoneReviewer, AlamatReviewer)

Primary Key : KodeReviewer

TbDosenPengusul (NIDN, Username, Password, NamaDosenPengusul,

PhoneDosenPengusul, AlamatDosenPengusul, DisiplinIlmuDosenPengusul,

ProgramStudiDosenPengusul, PangkatDosenPengusul,

JabatanFungsionalDosenPengusul)

Primary Key : NIDN

TbUsulan (KodeUsulan, JudulUsulan, BidangUsulan, BiayaUsulan, FileUsulan,

PeriodeUsulan)

Primary Key : KodeUsulan

TbKemajuan (KodeKemajuan, FileKemajuan)

Primary Key : KodeKemajuan

TbAkhir (KodeAkhir, FileAkhir)

Primary Key : KodeAkhir

Tipe entitas lemah dijelaskan dalam tabel berikut :

Tabel 12 Entitas Lemah

DetailUsulan (KodeUsulan, KodeReviewer)

Primary Key : KodeUsulan, KodeReviewer

DetailKemajuan (KodeKemajuan, KodeReviewer)

Primary Key : KodeKemajuan, KodeReviewer

DetailAkhir (KodeAkhir, KodeReviewer)

Primary Key : KodeAkhir, KodeReviewer

B. Penentuan batas integritas

Tujuan dari langkah ini ialah untuk menentukan integrity constraints yang ada sehingga dapat melindungi database dari keadaan yang tidak konsisten. Berikut referential integrity dijelaskan dalam tabel berikut

Tabel 13 Referential Integrity

TbSuperAdmin (KodeSuperAdmin, Username, Password, NamaSuperAdmin, 


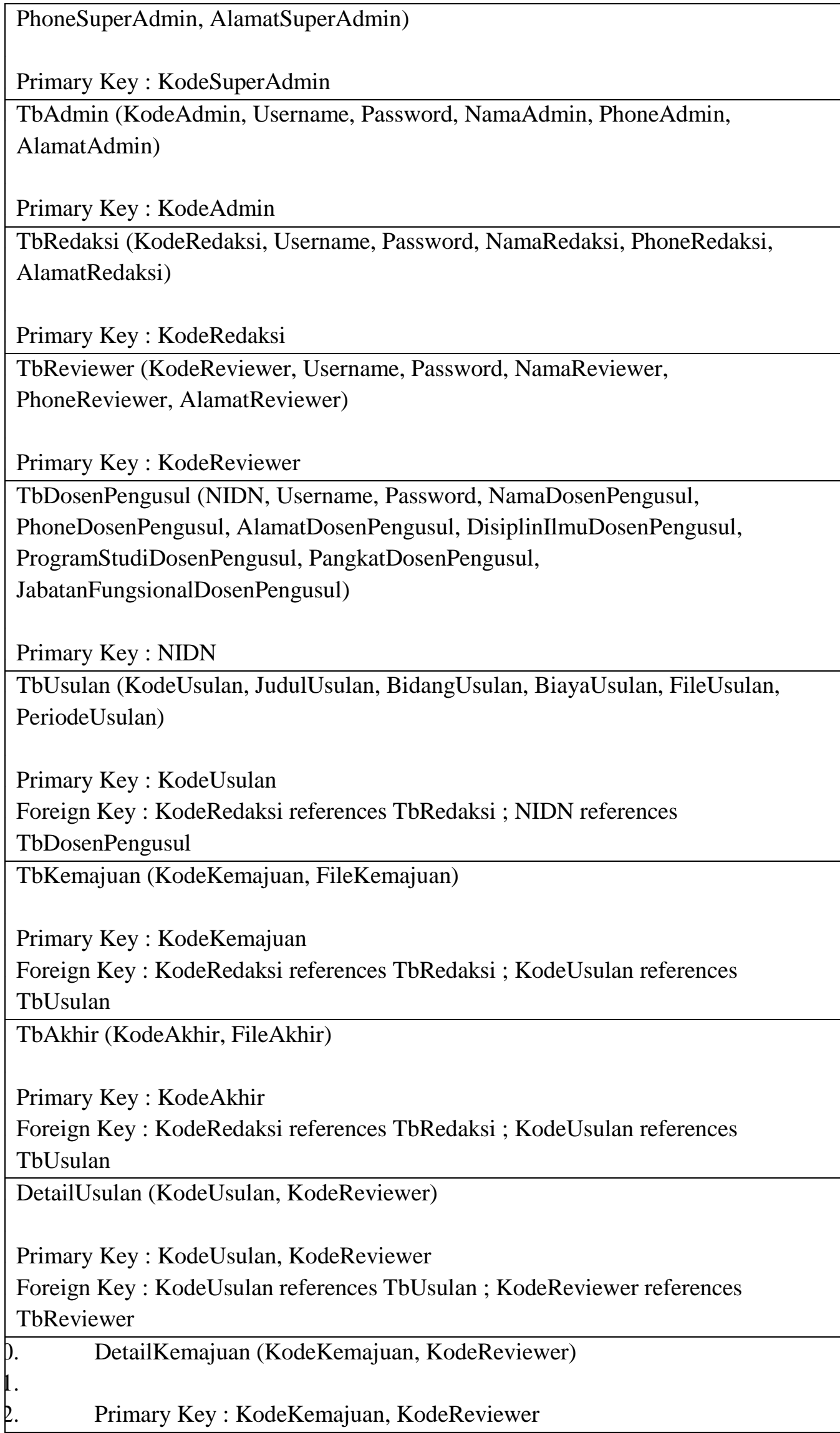




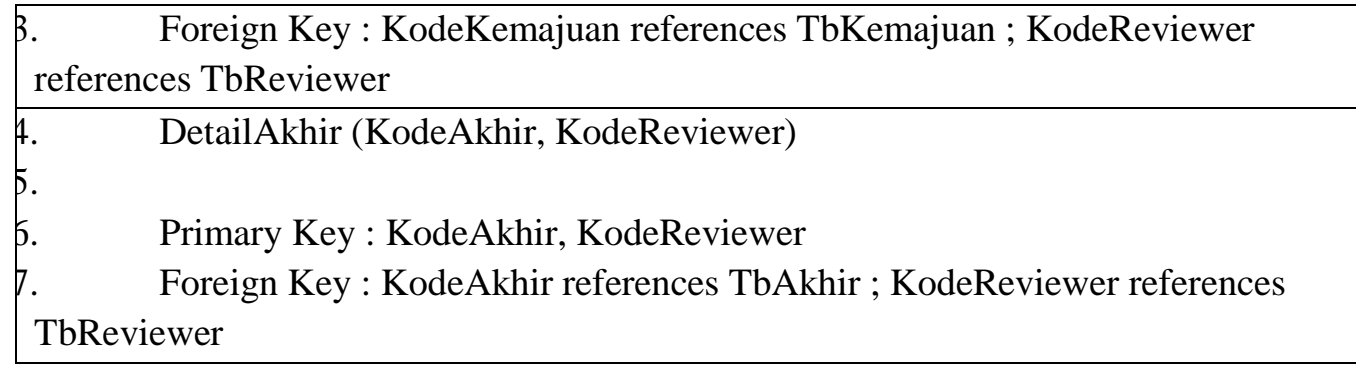

\subsubsection{Perancangan Fisikal}

Perancangan basis data fisikal adalah proses yang menghasilkan gambaran dari implementasi database pada secondary storage. Tahap ini menggambarkan penyusunan dan pemberian indeks file yang digunakan untuk mencapai akses data yang efisien, dan tingkat keamananan.

\section{A. Pemberian index pada file}

Tujuan dari langkah ini adalah mempertimbangkan pengaturan atau penyusunan file yang optimal untuk disimpan dalam base relation dan indeks yang dibutuhkan untuk mencapai performa yang diinginkan.

Tabel 14 Pemilihan Index

\begin{tabular}{|l|l|l|}
\hline \multicolumn{1}{|c|}{ Nama Tabel } & \multicolumn{1}{|c|}{ Index } & Nama Index \\
\hline TbSuperAdmin & $\begin{array}{l}\text { KodeSuperAdmin } \\
\text { (Primary Index) }\end{array}$ & Primary \\
\hline TbAdmin & $\begin{array}{l}\text { KodeAdmin (Primary } \\
\text { Index) }\end{array}$ & Primary \\
\hline TbRedaksi & $\begin{array}{l}\text { KodeRedaksi } \\
\text { (Primary Index })\end{array}$ & Primary \\
\hline TbReviewer & $\begin{array}{l}\text { KodeReviewer } \\
\text { (Primary Index })\end{array}$ & Primary \\
\hline TbDosenPengusul & $\begin{array}{l}\text { KodeDosenPengusul } \\
\text { (Primary Index) }\end{array}$ & Primary \\
\hline TbUsulan & $\begin{array}{l}\text { KodeUsulan (Primary } \\
\text { Index) }\end{array}$ & Primary \\
\hline TbKemajuan & $\begin{array}{l}\text { KodeKemajuan } \\
\text { (Primary Index) }\end{array}$ & Primary \\
\hline TbAkhir & $\begin{array}{l}\text { KodeAkhir (Primary } \\
\text { Index) }\end{array}$ & Primary \\
\hline
\end{tabular}

B. Mekanisme keamanan

Perancangan mekanisme keamanan pada website, terutama pada database juga akan dilakukan bersama user pada saat pengumpulan kebutuhan dan tahap-tahap analisis pada Database System Development Lifecycle. Umumnya, relational Database Management System (DBMS) menyediakan dua macam database security, yaitu System Security yang mencakup akses dan penggunaan database pada level sistem, seperti username dan password, serta Data Security yang mencakup akses dan penggunaan database objects seperti relasi dan view.

Tujuan dari langkah ini adalah untuk membuat mekanisme keamanan untuk database sebagaimana telah ditentukan oleh user. Ada tiga macam keamanan yang tersedia, yaitu: 
a. System Security, meliputi akses penggunaan database pada tingkat sistem, misalnya penggunaan username dan password. Aplikasi yang dirancang ini menggunakan halaman Login untuk melakukan otentikasi bagi pihak yang memiliki hak akses. Username dan password disimpan dalam lima tabel yang berbeda. Pertama dalam tabel TbSuperAdmin yang diperuntukkan bagi karyawan yang memiliki akses sebagai super admin, kedua TbAdmin yang diperuntukkan bagi karyawan yang memiliki akses sebagai admin penelitian dan pengabdian, ketiga TbRedaksi yang diperuntukkan bagi karyawan yang memiliki akses sebagai redaksi penelitian dan pengabdian, keempat TbReviewer yang diperuntukkan bagi Dosen yang memiliki akses sebagai reviewer dan kelima TbDosenPengusul yang diperuntukkan bagi Dosen yang memiliki akses sebagai pengusul. Atribut yang dipakai untuk otentikasi ini adalah Username dan Password. Username berupa string dengan panjang minimal 6 karakter dan maksimal 15 karakter, dan password juga berupa string dengan panjang minimal 6 karakter dan maksimal 20 karakter serta disimpan dalam database sebagai data yang telah dienkripsi. Username dan password bernilai NOT NULL atau tidak boleh kosong agar tidak terjadi kesalahan atau error dalam database.

b. Data security, meliputi data akses dan penggunaan obyek dalam database seperti table dan view di mana hanya pihak yang memiliki hak akses tertentu yang boleh menggunakan obyek dalam database tersebut. Data security tidak dilakukan pada tahap atau bagian database, namun akan digunakan dalam tahap aplikasi yaitu pemberian sesi pada pihak yang memiliki wewenang dalam mengakses suatu obyek dari aplikasi.

c. Operating System security, di mana aplikasi web dan database akan ditempatkan pada suatu operating system yang digunakan untuk mengelola aplikasi tersebut. Operating system tersebut memiliki akses keamanan berupa control panel yang memiliki login protocol di mana control panel tersebut tidak memungkinkan user untuk mengakses secara kasar pada OS tersebut. Control panel tersebut dijalankan pada web dengan protocol https atau http secure di mana protokol tersebut mengamankan koneksi kepada control panel dalam OS.

Berikut merupakan hak akses pengguna pada masing-masing entitas :

Tabel 15 Hak Akses

\begin{tabular}{|l|l|l|l|l|l|}
\hline \multirow{2}{*}{ Entitas } & \multicolumn{3}{|c|}{ Pengguna } \\
\cline { 2 - 6 } & $\begin{array}{c}\text { Super } \\
\text { Admin }\end{array}$ & Admin & Redaksi & Reviewer & $\begin{array}{c}\text { Dosen } \\
\text { Pengusul }\end{array}$ \\
\hline TbSuperAdmin & $\begin{array}{l}\text { R, U, D, } \\
\text { I }\end{array}$ & & & & \\
\hline TbAdmin & $\begin{array}{l}\text { R, U, D, } \\
\text { I }\end{array}$ & R, U, I & & & \\
\hline TbRedaksi & $\begin{array}{l}\text { R, U, D, } \\
\text { I }\end{array}$ & R, I & R, U, I & & \\
\hline TbReviewer & $\begin{array}{l}\text { R, U, D, } \\
\text { I }\end{array}$ & R, I & & R, U, I & \\
\hline TbDosenPengusul & $\begin{array}{l}\text { R, U, D, } \\
\text { I }\end{array}$ & R & & & R, U, I \\
\hline TbUsulan & R, U, D & R & R, I & R, I & R, U, I \\
\hline
\end{tabular}




\begin{tabular}{|l|l|l|l|l|l|}
\hline TbKemajuan & R, U, D & R & R, I & R, I & R, U, I \\
\hline TbAkhir & R, U, D & R & R, I & R, I & R, U, I \\
\hline DetailUsulan & R, U, D & R & R, I & R, I & \\
\hline DetaiKemajuan & R, U, D & R & R, I & R, I & \\
\hline DetailAkhir & R, U, D & R & R, I & R, I & \\
\hline
\end{tabular}

\section{KESIMPULAN}

Berdasarkan penelitian yang sudah dilakukan maka dapat disimpulkan bahwa hasil yang diperoleh pada penelitian ini terdiri atas :

1. Analisa terhadap proses yang sedang berjalan pada sistem eresearch, permasalahan yang ada serta usulan pemecahan masalah, perancangan basis data yang terdiri atas perancangan konseptual, logical, dan fisikal.

2. Menghasilkan perancangan basis data yang terintegrasi dengan baik

3. Hasil penelitian ini dapat digunakan oleh pengembang sistem dalam mengolah serta mengatur basis data pada sistem informasi eresearch STMIK STIKOM Bali.

[1] forlap.dikti.go.id

\section{DAFTAR PUSTAKA}

[2] Hardijanto, Didiek (2010). Kajian Basis Data Dalam Sistem Informasi Terpadu Pembangunan Prasarana Dan Sarana Dasar Perkotaan Di Kota Besar (Studi Kasus : Kota Bekasi), Masters thesis, Program Pascasarjana Universitas Diponegoro

[3] Edhy Sutanta, Ahmad Ashari. (2012). Distribusi Basis Data Kependudukan Untuk Optimalisasi Akses Data: Suatu Kajian Pustaka. Jurnal Ilmu Komputer Volume 5 No. 1 April 2012

[4] Connolly, T. (2002). Database Systems : A Practical Approach to Design, Implementation, and Management. (3rd edition). New York: Pearson Education.

[5] V.Post, G. (2002). Database Management Systems. New York: McGraw-Hill.

[6] Whitten. (2009). Systems analysis and design for the global enterprise. (7th edition). New York: McGraw-Hill.

[7] Marakas. (2006). Systems analysis and design : an active approach. New York: McGrawHill,

[8] Williams. (2007). Introduction Information Technology. New York: McGraw-Hill. 